\title{
Estimating Elasticity Function of Jordanian Aggregate Import Demand
}

\author{
Mohamed Ibrahim Mugableh ${ }^{1}$ \\ ${ }^{1}$ Head of Financial and Banking Sciences Department, College of Administrative and Financial Sciences, Irbid National \\ University, P.O Box: 2600-Zip Code: 21110, Jordan. \\ Correspondence: Mohamed Ibrahim Mugableh, Head of Financial and Banking Sciences Department, College of \\ Administrative and Financial Sciences, Irbid National University, P.O Box: 2600-Zip Code: 21110, Jordan.
}

\author{
Received: November 14, 2016 \\ Accepted: December 4, 2016 Available online: December 18, 2016 \\ doi:10.11114/aef.v4i2.2085 \\ URL: http://dx.doi.org/10.11114/aef.v4i2.2085
}

\begin{abstract}
This article estimates aggregate import demand function for Jordan using three fully co-integrating regressions over the (1980-2015) period. The bounds testing approach has been employed to test co-integration, while ARDL approach is used to analyze long-run elasticities. The results show a co-integration phenomenon among variables when import volume is dependent variable. In addition, the estimated long-run elasticities of import demand with respect to income and relative prices are 1.16 and -1.03 , respectively. The understanding of import demand behavior is crucial for significant import forecasts, international trade planning, and exchange rate policy design.
\end{abstract}

JEL: A1; C5; G1.

Keywords: ARDL, co-integration, elasticity, Jordan

\section{Introduction}

The cure objective of this article is to investigate co-integration and long-run elasticities between Jordanian's import demand and its determinants (i.e., income and import prices). However, numerous studies have been conducted to identify co-integration and estimate long-run elasticities of import demand function. Among them are Alam and Ahmed (2010) for Pakistan; Awang (1988), Tang and Mohammad (2000), and Tang and Nair (2002) for Malaysia; Babatunde and Egwaikhide (2010) for Nigeria; Tang (2002) for Indonesia.

A few empirical studies that conducted to examine the determinants of import demand on the Jordanian case contain certain methodological drawbacks (Kreishan, 2007; Majeed, 2007). The methodological techniques that employed in these studies such as Engle and Granger (1987) and Johansen and Juselius (1990) co-integration tests could affect the results obtained from them. For example, Johansen and Juselius (1990) multivariate co-integration test fails to recognize the mixture of stationary time-series variables (i.e., I(0), I(1), and I(2)). Harris (1995) argued that trace and maximum eigenvalues under Johansen and Juselius (1990) multivariate co-integration test could lead to statistical explosive if the I(0) variables are present in the system. In addition, Mah (2000) stated that the conventional co-integration tests (i.e., Engle and Granger (1987) and Johansen and Juselius (1990)) are not reliable for studying small sample size. Thus, a more robust estimation approach - the bounds testing - proposed by Pesaran et al. (2001) is employed in this study. The balance of this paper is organized as the following way. Section 2 discusses methodology and empirical results. Section 3 provides concluding remarks.

\section{Methodology and Empirical Results}

In this study, the following specification is considered for import demand function see Tang and Nair (2002):

$$
\mathrm{M}_{\mathrm{t}}=f\left(\mathrm{Y}_{\mathrm{t}}, \mathrm{MP}_{\mathrm{t}}\right)
$$

Where, $\mathrm{M}_{\mathrm{t}}$ is the aggregate imports quantity (goods and services) demanded at period t expressed in local currency unit Jordanian Dinar (JD); $\mathrm{Y}_{\mathrm{t}}$ is the income, gross domestic product (GDP) per capita, expressed in $\mathrm{JD}$; $\mathrm{MP}_{\mathrm{t}}$ is the import value index $(2010=100)$. However, the sample used in the current study covers annual observations for the (1980-2015) period. The raw time-series data is obtained from World Bank, Development Indicators Databases (2016). The import demand function in economy can be fully modeled by two factors (i.e., the GDP per capita and import value index). The import value index includes commodity adjusted for exchange rate, which gives a measure of real exchange rate. The log-linear formulation is more appropriate than the linear one (Eq. (1)). The log-linear specification avoids 
some estimation problems, particularly skewness, heteroscedasticity, and multicollinearity (Mugableh, 2015a). Thus, the log-linear specification is shown as in Eq. (2).

$$
\log M_{t}=\beta_{0}+\beta_{1} \log Y_{t}+\beta_{2} \log M P_{t}+\varepsilon_{t}
$$

Where, $\varepsilon_{t}$ is the white noise term distributed with zero mean and constant variance (i.e., $\varepsilon_{t} \sim N\left(0, \sigma^{2}\right)$ ). Based on the economic theory, the signs of coefficients are expected to be as follows: $\beta_{1}>0$ and $\beta_{2}<0$. A positive relationship is hypothesized between income and imports, while an inverse relationship is expected between price and imports. However, the results of correlation matrix in Table 1 show that the variables are linearly correlated between each other. This implies the appropriate estimation of import demand function in Jordan.

The second step is to determine the order of integration, $\mathrm{I}(\mathrm{d})$, for the variables before applying co-integration analysis, like bounds F-statistics test. The application of bounds F-statistics test is based on assumption that none of variables are integrated at level more than one (Pesaran et al., 2001). Phillips and Perron (1988) unit root test is designed to be robust for the presence of autocorrelation. The results of Phillips and Perron (1988) test in Table 2 show that all variables are stationary at I(1). Thus, the current study employs bounds F-statistics test under the ARDL approach framework (see Eq. (3)). This approach has a major advantage over conventional co-integration tests (i.e., Engle \& Granger, 1987; Johansen \& Juselius, 1990). That is, it can be applied irrespective of whether the series variables are integrated of order I(1), I(0), or mixed (Almsafir et al., 2011; Bekhet \& Mugableh, 2012; Bekhet \& Mugableh, 2013; Bekhet \& Mugableh, 2016; Mugableh, 2015b; Mugableh, 2015c; Mugableh, 2015d; Mugableh, 2013; Narayan, 2005). In fact, if the variables are stationary at $\mathrm{I}(0)$, the regression analysis might yield biased results when using conventional co-integration tests. These tests are applicable when variables are stationary at same order of integration (i.e., I(1) or I(2)).

$$
\begin{aligned}
& \Delta \log \mathrm{M}_{\mathrm{t}}=\alpha_{0}+\alpha_{1} \log \mathrm{M}_{\mathrm{t}-1}+\alpha_{2} \log _{\mathrm{t}-1}+\alpha_{3} \operatorname{LogMP}_{\mathrm{t}-1}+ \\
& \sum_{\mathrm{s}=0}^{\mathrm{h}} \alpha_{4} \Delta \log \mathrm{M}_{\mathrm{t}-\mathrm{s}}+\sum_{\mathrm{s}=0}^{\mathrm{h}} \alpha_{5} \Delta \log \mathrm{Y}_{\mathrm{t}-\mathrm{s}}+\sum_{\mathrm{s}=0}^{\mathrm{h}} \alpha_{6} \Delta \operatorname{LogMP}_{\mathrm{t}-\mathrm{s}}+\mathrm{EcM}_{\mathrm{t}-1}+\varepsilon_{\mathrm{t}}
\end{aligned}
$$

Where, $\Delta$ signifies the first difference operator; $\alpha_{0}$ is the drift component; $\varepsilon_{t}$ stands for white noise error term; $\alpha_{1}, \alpha_{2}$, and $\alpha_{3}$ represent the long-run coefficients of one lagged variables; $h$ is the lag length; $\alpha_{4}, \alpha_{5}$, and $\alpha_{6}$ are the short-run coefficients of first difference variables.

Narayan (2005) proposed that the bounds test is based on Wald or F-statistics for co-integration analysis. In Eq. (3), the null Hypothesis $\left(\mathrm{H}_{0}\right)$ of no co-integration considers the coefficients of one lagged variables (i.e., $\log \mathrm{M}_{\mathrm{t}-1}, \log \mathrm{Y}_{\mathrm{t}-1}$, and $\left.\log \mathrm{MP}_{\mathrm{t}-1}\right)$. For conventional significance levels of $1 \%, 5 \%$, and $10 \%$, if the computed $\mathrm{F}$-statistics value is lesser than the F-statistics critical value at level $\mathrm{I}(0)$, the $\mathrm{H}_{0}$ would be accepted. In contrast, if the computed F-statistics value is larger than the F-statistics critical value at level $\mathrm{I}(1)$, the $\mathrm{H}_{0}$ would be rejected, implying the existence of long-run relationships among variables. From the estimated ARDL approach, the long-run elasticities are the coefficients of one lagged independent variables multiplied by negative signs and divided by coefficient of one lagged dependent variable (Bardsen, 1989). Therefore, the long-run relative price elasticity and income elasticity are $-\left(\alpha_{3} / \alpha_{1}\right)$ and $-\left(\alpha_{2} / \alpha_{1}\right)$, respectively. The short-run effects are captured by the coefficients of first differenced variables in Eq. (3).

In selecting the lag length (h), a set of estimations is conducted with $h=1,2$, and 3. Nevertheless, the Akaike information criterion (AIC) and Schwartz information criterion (SIC) fail to give a final decision. The $\mathrm{h}=1$ is selected based on AIC and $\mathrm{h}=2$ is selected based on SIC. To select the best-fit specification, the Ramsey RESET test with $\mathrm{h}=2$ is chosen. For $\mathrm{h}=2$, the $\log$ likelihood computed value is 0.30 (probability $=0.62$ ), accepting the $\mathrm{H}_{0}$ of no misspecification. For $\mathrm{h}=1$, the Ramsey Reset test was statistically significant at the 5\% level, hence, rejecting the $\mathrm{H}_{0}$ of no misspecification.

Table 1. Screening data statistics tests

\begin{tabular}{llll}
\hline & $\log \mathrm{M}_{\mathrm{t}}$ & $\log \mathrm{Y}_{\mathrm{t}}$ & $\operatorname{LogMP}_{\mathrm{t}}$ \\
\hline Mean & 3.71 & 1270.13 & 140.33 \\
Standard deviation & 1.10 & 204.805 & 118.46 \\
Jarque-Berra & 4.79 & 2.81 & 10.7 \\
P-value & 0.10 & 0.25 & 0.11 \\
$\mathrm{R}^{2}$ & 0.86 & & \\
Adjusted & \\
\hline Correlation matrix & 0.85 & & \\
\hline LogM $_{\mathrm{t}}$ & 1.00 & & \\
LogY $_{\mathrm{L}}$ & 0.67 & 1.00 & 1.00 \\
LogMP $_{\mathrm{R}}$ & 0.82 & 0.75 &
\end{tabular}

Notes: (1) $\mathrm{R}^{2}$ denotes the coefficient of determination. (2) Source: E-Views econometrics software package. 
Table 2. Unit root test results

\begin{tabular}{llllll}
\hline \multirow{2}{*}{ Variable } & \multicolumn{4}{l}{$\mathrm{t}$-statistics computed values } & \multicolumn{3}{l}{$\mathrm{t}$-statistics critical values } \\
\cline { 2 - 5 } & $\mathrm{I}(0)$ & $\mathrm{I}(1)$ & $1 \%$ & $5 \%$ & $10 \%$ \\
\hline $\operatorname{LogM}_{\mathrm{t}}$ & -1.90 & $-5.28^{* * * *}$ & & \\
$\operatorname{LogY}_{\mathrm{t}}$ & -0.81 & $-4.15^{* *}$ & -4.27 & -3.56 & -3.21 \\
$\operatorname{LogMP}_{\mathrm{t}}$ & 0.26 & $-5.89^{* * *}$ & & & \\
\hline
\end{tabular}

Notes: (1) The estimation has been conducted using intercept and time trend. (2) Parzen Kernel estimation method has been selected to choose the bandwidth: 2. (3) ${ }^{* * *},{ }^{* *}$ denote the significance at $1 \%$ and $5 \%$ levels, respectively based on Mackinnon (1996) one side p-values. (4) Source: E-Views econometrics software package.

The estimated long-run and short-run elasticities results are reported in Table 3. The estimated long-run income elasticity and relative price elasticity are 1.16 and -1.03 , respectively. These results are found to be closer with the previous study's results of Tang and Nair (2002) in Malaysia. They found that the long-run income elasticity and relative price elasticity are 1.55 and -1.30 , respectively. The coefficient of $\operatorname{EcM}_{t-1}(-0.67)$ is negative and is statistically significant, confirming that the series is non-explosive and that long-run equilibrium is satisfied.

Table 3. The estimated ARDL approach for Jordanian import demand function

\begin{tabular}{lll}
\hline Variable & Coefficient & t-statistics \\
\hline Constant & $12.1^{* * * *}$ & 2.90 \\
$\operatorname{LogM}_{\mathrm{t}-1}$ & $0.37^{*}$ & 1.88 \\
$\log _{\mathrm{t}-1}$ & 0.43 & 1.02 \\
$\operatorname{LogMP}_{\mathrm{t}-1}$ & $-0.38^{*}$ & -1.74 \\
$\Delta \log \mathrm{t}_{\mathrm{t}}$ & -0.01 & -0.06 \\
$\Delta \operatorname{LogMP}_{\mathrm{t}}$ & $0.26^{* * *}$ & 3.81 \\
EcM $_{\mathrm{t}-1}$ & $-0.67^{* * *}$ & -4.20 \\
\hline
\end{tabular}

Notes: (1) ${ }^{* * * * *}$ denote the significance at $1 \%$ and $10 \%$ levels, respectively. (2) The dependent variable is $\Delta$ LogM $_{\mathrm{t}}$. (3) Sample: 1980-2015 included 36 observations. (4) Durbin-Watson statistics value: 1.57. (5) F-statistics value: 6.17 (p-value: 0.00). (6) Source: Micro-Fit econometrics software package.

To ascertain the existence of a long-run relationship or co-integration among the variables, the bounds F-statistics test is employed under the ARDL approach framework. However, the results of the bounds F-statistics test (Table 4) show that the computed F-statistics value (6.55) exceeds the bounds F-statistics critical value (5.82) at the $1 \%$ significance level. This implies that volume of imports and its determinants (i.e., national income and relative price) are co-integrated or co-moving.

Table 4. Co-integration test results

\begin{tabular}{|c|c|c|c|c|c|c|c|}
\hline Function & $\begin{array}{l}\text { Computed } \\
\text { value }\end{array}$ & \multicolumn{6}{|c|}{ Tabulated F-statistics values } \\
\hline \multirow{3}{*}{$\begin{array}{l}\log M_{t-1}=f\left(\log Y_{t-1},\right. \\
\left.\log P_{t-1}\right)\end{array}$} & \multirow{3}{*}{$\begin{array}{l}6.55^{*} \\
(\text { Lag structure, } h=2)\end{array}$} & $1 \%$ & & $5 \%$ & & $10 \%$ & \\
\hline & & $\mathrm{I}(1)$ & $\mathrm{I}(0)$ & $\mathrm{I}(1)$ & $\mathrm{I}(0)$ & $\mathrm{I}(1)$ & $\mathrm{I}(0)$ \\
\hline & & 5.82 & 4.43 & 4.19 & 3.16 & 3.53 & 2.62 \\
\hline
\end{tabular}

Notes: (1) The tabulated F-statistics values were retrieved from Narayan (2005, Case II: restricted intercept and no trend, p. 1987). (2) ${ }^{*}$ denotes the significance at $1 \%$ level. (3) Source: The computed F-statistic value was obtained from Micro-Fit econometrics software package.

\section{Concluding Remarks}

The main objective of this article is to reexamine the Jordanian import demand function over the (1980-2015) period using a more robust estimation model, namely the ARDL approach. The results of bounds F-statistics test disclose that the import volume and its determinants are co-integrated. The findings of estimated long-run elasticity for income and relative prices are 1.16 and -1.03 , respectively. From the above conclusions, two policy implications could be briefed. First, the Marshall-Lerner condition is satisfied. That is, Salvatore (1995) argued that a stable foreign exchange market exists if the sum of price elasticities of demand for imports and exports, in absolute value, is larger than one. Second, based on the estimated relative price elasticity, the import volume is sensitive to the increases in domestic price levels. Therefore, any increase in domestic inflation rates would generate a higher volume of imports. In this manner, the Jordanian policy makers ought to employ severe fiscal and monetary policies to keep inflation at reasonable rates.

\section{References}

Alam, S., \& Ahmed, Q. M. (2010). Exchange rate volatility and Pakistan's import demand: An application of autoregressive distributed lag model. International Research Journal of Finance and Economics, 48, 7-23. http://www.academia.edu/6213934/Exchange_Rate_Volatility_and_Pakistans_Import_Demand_An_Application_o f_Autoregressive_Distributed_Lag_Model 
Almsafir, M. K., Abdul Latif, N. W. B., \& Bekhet, H. A. (2011). Analyzing the green field investment in Malaysia from 1970-2009: A bound testing approach. Australian Journal of Basic and Applied Sciences, 5(3), 561-570. https://www.researchgate.net/publication/250305291_Analyzing_the_Green_Field_Investment_in_Malaysia_From _1970_to_2009_a_Bound_Testing_Approach

Awang, A. H. (1988). An evaluation of the structural adjustment policies in Malaysia. In Proceeding of the Eight Pacific Basin Central Bank Conference on Economic Modelling, Bank Negara Malaysia, Kuala Lumpur, November 11-15.

Babatunde, M. A., \& Egwaikhide, F. O. (2010). Explaining Nigeria's import demand behavior: a bounds testing approach. International Journal of Development Issues, https://doi.org/10.1108/14468951011062354

Bardsen, G. (1989). Estimation of long-run coefficients in error correction models. Oxford Bulletin of Economics and Statistics, 51, 345-350. https://doi.org/10.1111/j.1468-0084.1989.mp51003008.x

Bekhet, H. A., \& Mugableh, M. I. (2012). Investigating equilibrium relationships between macroeconomic variables and Malaysian stock market index through bounds tests approach. International Journal of Economics and Finance, 4(10), 69-81. https://doi.org/10.5539/ijef.v4n10p69

Bekhet, H. A., \& Mugableh, M. I. (2013). Examining the equilibrium relationships between foreign direct investment inflows and employment in manufacturing and services sectors: evidence from Malaysia. Journal of Social and Development Sciences, 4(1), 32-38.

https://www.researchgate.net/publication/253330028_Examining_the_Equilibrium_Relationships_between_Foreig n_Direct_Investment_Inflows_and_Employment_in_Manufacturing_and_Services_Sectors_Evidence_from_Mala ysia

Bekhet, H. A., \& Mugableh, M. I. (2016). Blueprinting the equilibrium relationships between inward FDI and employment in the Malaysian economic sectors: time series models approach. Global Business and Economics Review, 18(2), 136-150. https://doi.org/10.1504/GBER.2016.075507

Engle, R. F., \& Granger, C. W. J. (1987). Co-integration and error correction: Representation estimation and testing. Econometrica, 55(2), 251-276. https://doi.org/10.2307/1913236

Harris, R. I. D. (1995). Using co-integration analysis in econometric modeling ( $1^{\text {st }}$ ed.). A Pearson Education Company Publisher. England: London. https://www.jstor.org/stable/2285206?seq=1\#page_scan_tab_contents

Johansen, S., \& Juselius, K. (1990). Maximum likelihood estimation and inference on co-integration-with applications to the demand for money. Oxford Bulletin of Economics and Statistics, 52, 169-210. https://doi.org/10.1111/j.1468-0084.1990.mp52002003.x

Kreishan, F. (2007). Estimating an import function for Jordan: a co-integration analysis. Dirasat, Administrative Sciences, 34(2), 407-415. http://journals.ju.edu.jo/DirasatAdm/article/view/417

Mackinnon, J. (1996). Numerical distribution functions for unit root and co-integration tests. Journal of Applied Econometrics, 11, 601-618. https://doi.org/10.1002/(SICI)1099-1255(199611)11:6<601::AID-JAE417>3.0.CO;2-T

Mah, J. S. (2000). An empirical examination of the disaggregated import demand for Korea - the case of information technology products. Journal of Asian Economics, 11, 237-244. https://doi.org/10.1016/S1049-0078(00)00053-1

Majeed, H. (2007). Estimating long-run elasticities of Jordanian import demand function: 1980-2004 an application of dynamic OLS. Applied Economics and International Development, 7(2), 171-182. http://www.usc.es/economet/journals1/aeid/aeid7215.pdf

Mugableh, M. I. (2013). Analysing the $\mathrm{CO}_{2}$ emissions function in Malaysia: Autoregressive distributed lag approach. Procedia Economics and Finance, 5, 571-580. https://doi.org/10.1016/S2212-5671(13)00067-1

Mugableh, M. I. (2015a). Time series analysis of inward foreign direct investment function in Malaysia. Procedia Social and Behavioral Sciences, 172, 679-685. https://doi.org/10.1016/j.sbspro.2015.01.419

Mugableh, M. I. (2015b). Economic growth, $\mathrm{CO}_{2}$ emissions, and financial development in Jordan: Equilibrium and dynamic causality analysis. International Journal of Economics and Finance, 7(7), 98-105. https://doi.org/10.5539/ijef.v7n7p98

Mugableh, M. I. (2015c). Equilibrium models of the Malaysian stock market and macro economy ( $1^{\text {st }}$ ed), LAP LAMBERT Academic Publishing. Germany: Berlin. https://www.amazon.com/Equilibrium-Models-Malaysian-Market-Macroeconomy/dp/3659788708 
Mugableh, M. I. (2015d). Aggregate economic forces and Malaysian equity market: Equilibrium time-series approach. $4^{\text {th }}$ International Conference on Management, Finance \& Entrepreneurship. https://www.researchgate.net/profile/Mohamed_Mugableh/publications

Narayan, P. K. (2005). The saving and investment nexus for China: evidence from co-integration tests. Applied Economics, 37(17), 1979-1990. https://doi.org/10.1080/00036840500278103

Pesaran, M. H., Shin, Y., \& Smith, R. J. (2001). Bounds testing approach to the analysis of level relationships. Journal of Applied Econometrics, 16, 289-326. https://doi.org/10.1002/jae.616

Phillips, P. C. B., \& Perron, P. (1988). Testing for a unit root in time series regression. Biometrika, 75, 335-346. https://doi.org/10.1093/biomet/75.2.335

Salvatore, D. (1995). International Economics (5 ${ }^{\text {th }}$ ed), Macmillan. USA: New York.

Tang, T. C. (2002). Aggregate import demand behavior for Indonesia: evidence from bounds testing approach. IIUM Journal of Economics and Management, 10(2), 1-21. https://www.researchgate.net/publication/46533772_AGGREGATE_IMPORT_DEMAND_BEHAVIOR_FOR_IN DONESIA_EVIDENCE_FROM_THE_BOUNDS_TESTING_APPROACH

Tang, T. C., \& Mohammad, H.A. (2000). An aggregate import demand function for Malaysia: a co-integration and error correction analysis. Utara Management Review, 1, 43-57. http://repo.uum.edu.my/496/

Tang, T. C., \& Nair, M. (2002). A co-integration analysis of Malaysian import demand function: reassessment from the bounds test. Applied Economic Letters, 9, 293-296. https://doi.org/10.1080/13504850110073471

World Bank, Development Indicators Databases (2016). Available on line at: http://data.worldbank.org/data-catalog/world-development-indicators, accessed on May 30, 2016

\section{Copyrights}

Copyright for this article is retained by the author(s), with first publication rights granted to the journal.

This is an open-access article distributed under the terms and conditions of the Creative Commons Attribution license which permits unrestricted use, distribution, and reproduction in any medium, provided the original work is properly cited. 